\title{
Long-Term Effects of Cesarean Births on Unintended Pregnancy Rates and Obstetric Expenditures
}

\author{
Kahraman Ülker, İsmail Temur, Abdülaziz Gül \\ Kafkas Üniversitesi Tip Fakültesi Kadın Hastalılarn ve Doğum Anabilim Dal, Kars, Türkiye
}

\begin{abstract}
Objective: To study the long-term effects of the cesarean and vaginal births on unintended pregnancy rates and the obstetric costs. Methods: Parous women $(n=501)$ were grouped into two in accordance to the mode of their first two births as: vaginal birth group with two subsequent vaginal births and cesarean birth group with at least one cesarean birth. Turkish Republic Social Security Institution payment values in 2010 were used as the cost standards. Means of parity, ectopic pregnancy, spontaneous abortion and voluntary abortion were used to calculate the life time obstetrics expenditure of the groups. The calculated values were divided to each group's mean reproductive time to find out the expenditure per reproductive year. In statistical analysis Student's t test or analysis of variance tests were used. A p value of $\leq 0.05$ was considered statistically significant.
\end{abstract}

Results: Vaginal group had significantly higher gravidity, parity and voluntary abortion rates $(p<0.05)$. The means of the age of the participating women, spontaneous abortions and ectopic pregnancies were similar in both groups $(p>0.05)$. The total number of pregnancies, births, spontaneous abortions, voluntary abortions and offspring decreased significantly in each decade $(p<0.05)$. Hospital births significantly increased in each decade, reaching from $48.29 \%$ in 70 s to $88.08 \%$ in 1990 s. The obstetric expenditure for a single woman in a reproductive year time was found 71.92 Turkish Liras in vaginal and 53.41 Turkish Liras in cesarean birth groups.

Conclusion: Cesarean birth decreases the total obstetric costs in long term, particularly in areas with high fertility rates.

Keywords: Cesarean section, cesarean section rate, mode of birth, cost control, obstetrics economics, elective surgical procedure.

\section{Sezaryen doğumların istenmeyen gebelik oranı ve obstetrik harcamalar üzerine uzun dönem etkileri}

Amaç: Sezaryen ve vajinal doğumların istenmeyen gebelik oranı ve obstetrik harcamalar üzerine uzun dönem etkilerini araştırmak.

Yöntem: Daha önceden doğum yapmış kadınlar $(n=501)$ doğum yöntemine göre iki gruba ayrıldılar: Ilk iki gebeliğini vajinal doğuranlar vajinal doğum grubu ve ilk iki gebelikten en az birini sezaryen ile doğuranlar sezaryen doğum grubunu oluşturdu. Maliyet standartları için Türkiye Cumhuriyeti Sosyal Güvenlik Kurumu 2010 ödeme değerleri kullanıldı. Grupların ömür boyu obstetrik giderlerini hesaplamak için, ortalama doğum, dış gebelik, kendiliğinden ve istemli düşük oranları kullanıldı. Hesaplanan değerler her grubun ortalama tüketilmiş üreme yıllarına bölünerek, üreme yılı başına gider hesaplaması yapıldı. Istatistiksel analizde Student T testi ve varyans analizi (ANOVA) testleri kullanıldı. P değerinin $\leq 0.05$ olması istatistiksel olarak anlamlı kabul edildi.

Bulgular: Vajinal grubun gebelik, doğum ve istemli düşük oranları belirgin olarak daha yüksek bulundu $(p<0.05)$. Ortalama anne yaşı, kendiliğinden düşük ve dış gebelik sayıları ise her iki grupta benzerdi (p>0.05). Her 10 yıllık dönemde ortalama gebelik, doğum, kendiliğinden düşük, istemli düşük ve sahip olunan çocuk sayısı belirgin olarak azalmıştır $(p<0.05)$. Hastane doğum oranları da her 10 yılda belirgin olarak artmıştır. 1970'de \%48.29 olan hastane doğumu oranı, 1990'larda \%88.08'e ulaşmıştır. Üreme yılı başına obstetrik gider, bir kadın için vajinal doğum grubunda 71.92 Türk Lirası ve sezaryen doğum grubunda 53.41 Türk Lirası bulundu.

Sonuç: Özellikle doğurganlığın yüksek hızda olduğu bölgelerde, sezaryen doğum obstetrik giderleri uzun dönemde azaltır. Ama uzun dönem giderlere göre cerrahi karar vermek doğru olmayacaktır. Unutulmamalıdır ki, sağlık politikalarındaki değişiklikler bu gider hesaplamalarını tamamen değiştirebilir.

Anahtar Sözcükler: Sezaryen doğum, sezaryen doğum oranı, doğum yöntemi, maliyet kontrolü, obstetrik ekonomi, elektif cerrahi işlem. 


\section{Introduction}

Cesarean birth rates continuously rise in Turkey, like many other countries. ${ }^{[1-6]}$ The increase is generally associated with the women's request, physicians' choice, and previous cesarean birth, low level skill of primary care providers, injudicious use of uterotonics, changing demographics, altered clinical practice, and an increasing awareness of traumatic childbirth amongst the public. ${ }^{[7-10]}$ There are contraries in opinions about the rise in cesarean rates, particularly in cases of maternal request without any clinical indication for the surgery. ${ }^{[11,12]}$ One of the contraries is the cost of the procedures. The insurance companies are unwilling to pay for the cesarean births without an acceptable surgical indication, because the cesarean birth prices are generally more expensive than vaginal birth prices. However, the long-term costs are not well studied. Some researchers compared the costs of each vaginal and cesarean birth according to the expenditure made by the hospital and the patient; ${ }^{[13]}$ others compared the cost of each procedure with total perinatal expenditures. ${ }^{[14]}$ In our study we planned to compare the long-term costs of cesarean birth (CB) and vaginal birth (VB). Because the mode of birth may affect future pregnancy rates and the gestational outcomes, we used the parity and abortion rates to calculate a woman's mean life-time obstetrics expenditure. We hypothesized that, by decreasing the future birth and abortion rates, having at least one of the first two births by cesarean section would decrease the total obstetric expenditures spent for a woman.

\section{Methods}

The study was approved by the local Institutional review board of our university hospital and performed between January and October 2010 within our obstetrics and gynecology department. All patients gave informed consent before participating in the study. To study the long-term effects of the mode of delivery, parous women started to give births before $2000(n=501)$ were divided into two groups in accordance to the mode of their first two births as: vaginal birth group (VBG) with two subsequent vaginal births and cesarean birth group with at least one cesarean birth. A questionnaire was distributed to the partic- ipants to obtain demographic information such as maternal age, gravidity, parity, spontaneous abortion, induced abortion, ectopic pregnancy, number of offspring and their age. A nurse capable of speaking several local dialects helped the participants to fill in the questionnaires and provided assistance in cases of confusion, misunderstanding and illiteracy. After collecting the data, one of the authors checked the questionnaire form for the accuracy of the obtained data. Unreliable and incomplete data caused exclusion. Inconsistent and discordant data between variables like maternal age, first child's age and birth dates caused exclusions. Means of age, gravidity, parity, spontaneous and voluntary abortion, ectopic pregnancy, number of offspring with their age and gravidity-living offspring difference were calculated for each group. According to the reproductive years, the groups were further analyzed for giving the first birth between 1970-1980, 1980-1990, and 19902000. The decision for termination of a pregnancy may be influenced by the actual family size. Most of the time, the unintended pregnancies are terminated if the family has reached the desired number of offspring. To eliminate the effect of family size, women having two or more offspring were included. In addition, a woman's age and reproductive year stage could influence the decision of pregnancy termination. The range for reproductive years was defined as 15-49 years. 15 years were subtracted from actual maternal age to calculate the bygone reproductive years. In cases of women older than $49(45-15=34)$, reproductive years were considered as 34 . The total cost calculation we used was not a real cost effectiveness calculation. It did not reflect the actual cost for each procedure at the time of the study. We did not calculate the real market prices of the expenditures. We used Turkish Republic Social Security Institution's 2010 payment values as the cost standards during the calculation. For year 2010 the institute pays 450 Turkish Liras (TL) for cesarean birth, 400 TL for vaginal birth, $455 \mathrm{TL}$ for the management of ectopic pregnancy and 200 TL for the management of spontaneous or voluntary abortion. In our study the total cost (TC) of the mode of birth (MB) for each woman was calculated by using the formula: $\mathrm{TCMB}=$ (Mean number of births according to the $\mathrm{MB} \times$ cost of the MB) + (Mean count of spontaneous abortion according to the MB x cost of spon- 
taneous abortion treatment)+ (Mean count of voluntary abortion according to the $\mathrm{MB} \times \mathrm{x}$ cost of voluntary abortion treatment)+ (Mean count of ectopic pregnancy according to the $\mathrm{MB} \times \mathrm{x}$ cost of ectopic pregnancy treatment). To eliminate the effect of the maternal age and the stage of the reproductive years, the total costs of the groups were divided to the mean reproductive bygone times of their own group. The calculation represented the total obstetric expenditure for a reproductive year of a single woman. By using SPSS for Windows 16.0 package program the data were collected and analyzed. Vaginal birth and cesarean birth groups were compared using the independent sample Student $t$ test. Demographical data was compared by 10 year intervals from 1970 to 2000 using analysis of variance test (ANOVA). A p value of $<0.05$ was considered statistically significant.

\section{Results}

The demographical findings and their comparison results according to the mode of birth are summarized in Table 1 . The mean numbers of pregnancies, births and voluntary abortions were significantly higher in VBG $(\mathrm{p}<0.05)$. The means of the age of the participating women, spontaneous abortions and ectopic pregnancies were similar in both groups $(\mathrm{p}>0.05)$. The demographical findings and their comparison according to the years by ten year intervals are summarized in Table 2 . The total number of pregnancies, births, spontaneous abortions, voluntary abortions and offspring decreased significantly in each decade $(\mathrm{p}<0.05)$. The percentage of hospital births significantly increased in each decade, reaching from $48.29 \%$ in 70 s to $88.08 \%$ in 1990s. The total obstetric cost of a woman was found 1,940.55 Turkish Liras (TL) in VBG and 1,332.85 Turkish Liras in CBG. Although the maternal ages in both groups were not significantly different from each other, to eliminate the effect of the maternal age and the stage of the reproductive years, the total costs of the groups were divided to the mean bygone reproductive years of their own group. The mean bygone reproductive years were $26.98 \pm 6.82$ years in vaginal birth and $24.95 \pm 6.82$ years in cesarean birth groups and did not show significant difference $(\mathrm{p}>0.05)$. After dividing the costs by each group's own mean bygone reproductive year, the obstetric cost of a reproductive year of a woman was calculated. The yearly obstetric cost for a woman was found 71.92 Turkish Liras in VBG and 53.41 Turkish Liras in CBG. Reproductive failure was defined as the rates of the pregnancies that did not result in a living offspring. The difference of living offspring from the total pregnancies divided by

Table 1. Comparison of vaginal birth and cesarean birth groups data are presented as mean \pm standard deviation* or median."

\begin{tabular}{lcccccc}
\hline & Age* $^{*}$ (years) & Gravidity* & Parity $^{*}$ & Miscarriage $^{*}$ & $\begin{array}{c}\text { Induced } \\
\text { abortion }\end{array}$ & $\begin{array}{c}\text { Ectopic } \\
\text { pregnancy }\end{array}$ \\
\hline Vaginal birth group $(\mathrm{n}=458)$ & $42.72 \pm 7.78$ & 5 & 4 & 0 & 0 & 0 \\
Cesarean birth group $(\mathrm{n}=43)$ & $40.42 \pm 7.53$ & 3 & 2 & 0 & 0 & 0 \\
$\mathrm{p}$ & 0.06 & 0.00 & 0.00 & 0.61 & 0.00 & 0.11 \\
\hline
\end{tabular}

Table 2. Demographic changes of the 501 women by 10 year intervals. Data are presented as mean \pm standard deviation* or median."

\begin{tabular}{|c|c|c|c|c|}
\hline & $\begin{array}{c}1970-1980 \\
(n=105)\end{array}$ & $\begin{array}{c}1980-1990 \\
(n=181)\end{array}$ & $\begin{array}{c}1990-2000 \\
(n=215)\end{array}$ & $\mathbf{p}$ \\
\hline Age of the women at the timeof the study* & $50.66 \pm 3.56$ & $45.97 \pm 4.34$ & $35.651 \pm 5.41$ & 0.00 \\
\hline Gravidity & 7 & 5 & 4 & 0.00 \\
\hline Parity ${ }^{\#}$ & 5 & 4 & 3 & 0.00 \\
\hline Miscarriages ${ }^{\#}$ & 0 & 0 & 0 & 0.00 \\
\hline Induced abortion" & 1 & 1 & 0 & 0.00 \\
\hline Ectopic pregnancy ${ }^{\#}$ & 0 & 0 & 0 & 0.05 \\
\hline Offspring number" & 4 & 3 & 3 & 0.00 \\
\hline Hospital Births (\%)* & $48.29 \pm 46.51$ & $79.02 \pm 34.27$ & $88.08 \pm 29.23$ & 0.00 \\
\hline
\end{tabular}


the total number of pregnancies gave the failure rates for each group. The reproductive failure rate was $0.27 \pm 0.23$ in the VBG and $0.25 \pm 0.21$ in the CBG. Although the reproductive failure rate was found slightly higher in the VBG, the difference was not significant $(\mathrm{p}>0.05)$.

\section{Discussion}

In developing and overpopulated countries health resources are generally used in public hospitals instead of primary and preventive sectors. ${ }^{[13,15]}$ From this point of view, the high fertility rates, because of the inadequate primary family planning services, further increases the costs. The real obstetric costs differ between countries, cities and hospitals. The differences in health policies, production and providing costs of the medical and nonmedical outgoings, staff wages, and the life standards of the environment, poverty and affordability affect the costs of birth modes. ${ }^{[16-22]}$ Two different hospitals, even in the same region of a city, may have different incomes and expenses. The quality of medical and non-medical services may be different. We think that it is irrational to compare the costs of the vaginal and cesarean births by using the amount of the money spent for each procedure in different conditions. Our study was based on the effect of cesarean births on the pregnancy related events, like the number of births and abortions. From this point of view, differences in the production and providing costs of the medical and non-medical outgoings, staff wages and etc. do not change the power of this effect, and in the long term, cesarean births decrease the total expenditure of obstetric costs. Unintended pregnancies constitute half of all pregnancies (49\%) in the United States. Moreover, 52\% (approximately one third of all) of them result in an unintended birth. ${ }^{123]}$ In 20016.7 million women used the public family planning services in the United States. The expense per woman was $\$ 188$ ( $\$ 1.26$ billion in total). ${ }^{[2]}$ This amount is huge and unaffordable for most of the countries. In addition it could not provide a full contraceptive service for the whole community. In our study cesarean birth decreased the gravidity, parity and voluntary abortion rates, which resulted in a decrease in the unintended pregnancy and birth rates. Tubal sterilization or intra-operative intra-uterine device insertion during the same operation may facilitate the acceptance of contraceptive use. The rate of tubal sterilization during cesarean births is higher than interval sterilization. ${ }^{[25}$ The decreases in both total fertility and induced abortion rates can be explained by the women's more decided attitudes against unintended pregnancy. The hospital, operation and anesthesia experience and fear, the physician's orientation, the observed increased complication rates in the repeated operations, difficulty in baby care and the delay in returning to the job may be the causes of the decided attitude against the unintended pregnancies. Hospital births may also decrease the unintended pregnancy rates. Many women may have the first and only chance to benefit from a health and family planning service at the time of their births. Although, the hospital birth counts of the vaginal births increases continuously, the cesarean births are always in hospitals. In addition, the repeat cesarean births with their potential complications are always taken more seriously by the physicians and the pregnant women. The risk of the complications of all the obstetrical and gynecological operations increases after each repeated cesarean section, which may orient the physicians to give stricter advices and orders about the unintended pregnancies. The decrease in total fertility and induced abortions rates after cesarean births should be further studied. In this manner, the role of intra-partum contraception, hospital births, the women's educational and socio-economic status, physician's orientation, health politics and the scientific advances in health management need to be determined by multi-center studies. Many women request for cesarean births. We think that after giving an informed consent, those women should be respected and promoted for their decisions. Whatever the causes are, cesarean section decreases the rates of pregnancy, births and voluntary abortions. This effect should also be considered in the comparison of the risks of cesarean and vaginal births.

\section{Conclusion}

If one of the first two births is a cesarean birth, the pregnancy, birth and voluntary abortion rates decrease. Moreover, the obstetric costs also decrease in long term. In cases of maternal request cesarean births may be acceptable, particularly in the regions with high fertility rates and poor family planning services. However, the decrease in the 
long-term expenditure, pregnancy, birth and voluntary abortions is not a surgical indication. Our data may possibly influence the surgical indication in the future. However, this influence may be acceptable only after the prospective studies which show equal safety for the cesarean births and the vaginal births. It should be kept in mind that changes in health politics and efficient contraception against the unintended pregnancies can totally change these expenditure calculations.

\section{References}

1. Center for disease control and prevention. Births: Preliminary data for 2005.-http://www.cdc.gov/nchs/ products/pubs/pubd/hestats/prelimbirths05/prelimbirths05.htm Mayis 31, 2006.

2. Coskun A, Kotsu B, Ercan O, Kiran H, Guven MA, Kiran G. Kahramanmaraş il merkezinde 2004 ve 2006 yıllarındaki doğumların karş1laştırılması. Journal of Turkish Obstetric and Gynecology Society 2007;4:168-72.

3. Meikle SF, Steiner CA, Zhang J, Lawrence WL. A national estimate of the elective primary cesarean birth rate. Obstet Gynecol 2005;105:751-6.

4. Lin HC, Xirasagar S. Institutional factors in cesarean birth rates: policy and research implications. Obstet Gynecol 2004; 103:128-13.

5. Özkaya O. Birth rates and cesarean indications at Süleyman Demirel University Obstetrics and Gynecology Clinic through a 5-year period. SDÜ Tip Fak Derg 2005;12:36-9.

6. Guney M, Uzun E, Oral B, Sarıkan I, Bayhan G, Mungan T. Cesarean section rates and indications at our clinic between 2001 and 2005. Türkiye Klinikleri J Gynecol Obst 2006;3:249-54.

7. Yaşar O, Şahin FK, Coşar E, Koken GN, Çevrioğlu AS. Birth method choices of primiparous women and the factors which have an effect on these choices. Türkiye Klinikleri J Gynecol Obst 2007; 17:414-20.

8. Shamshad. Factors leading to increased cesarean section rate. Gomal Journal of Medical 2008;6:1-5.

9. Farrell SA, Basket TF, Farrell KD. The choice of elective cesarean birth in obstetrics: a voluntary survey of Canadian health care professionals. Int Urogynecol J 2005;16:378-83.

10. Dietz HP. Elective cesarean section- the right choice for whom? Current Women's Health Review 2005;1:85-8.
11. Bewley S, Cockburn J. II. The unfacts of 'request' caesarean section. BJOG 2002;109:597-605.

12. Hannah M. Planned elective cesarean section: A reasonable choice for some women? CMAJ 2004;170:813-4.

13. Khan A, Zaman S. Costs of vaginal birth and Caesarean section at a tertiary level public hospital in Islamabad, Pakistan. BMC Pregnancy Childbirth 2010;10:2; DOI (eadres): http://www.ncbi.nlm.nih.gov/pmc/articles/ PMC2826286/ (baskida).

14. Palencia R, Gafni A, Hannah ME, Ross S, Willan AR, Hewson $\mathrm{S}$ et al. The costs of planned cesarean versus planned vaginal birth in the Term Breech Trial. CMAJ 2006;174(8);DOI (e-adres): http://www.cmaj.ca/cgi/ content/full/174/8/1109 (baskıda).

15. Tabish SA, Mustaffa A, Rangrez RA. Hospital accounting based cost studies: Indian experience. J Academy of Hospital Administration 2005;13:1-6.

16. Hendrix MJ, Evers SM, Basten MC, Nijhuis JG, Severens JL. Cost analysis of the Dutch obstetric system: low-risk nulliparous women preferring home or short-stay hospital birth-a prospective non-randomised controlled study. BMC Health Serv Res 2009; 9:211;DOI (e-adres): http://www.ncbi.nlm.nih.gov/pmc/articles/PMC2784768/?t ool=pubmed (baskida).

17. Vander Plaetse B, Hlatiwayo G, Van Eygen L, Meessen B, Criel B. Costs and revenue of health care in a rural Zimbabwean district. Health Policy Plan 2005;20:243-51.

18. Minh HV, Giang KB, Huong DL, Huong le T, Huong NT, Giang PN, Hoat LN, Wright P. Costing of clinical services in rural district hospitals in northern Vietnam. Int $J$ Health Plann Manage 2010;25:63-73.

19. Adam T, Evans DB, Murray CJ. Econometric estimation of country-specific hospital costs. Cost Eff Resour Alloc 2003;1:3; DOI (e-adres): http://www.resourceallocation.com/content/1/1/3 (baskida).

20. Nahar S, Costello A. The hidden cost of 'free' maternity care in Dhaka, Bangladesh. Health Policy Plan 1998;13:417-22.

21. Lagarde M, Palmer N. The impact of user fees on health service utilization in low- and middle-income countries: how strong is the evidence? Bull World Health Organ 2008;86:839-48.

22. Olukoga A. Unit costs of inpatient days in district hospitals in South Africa. Singapore Med J 2007;48:143-7.

23. Frost, J, Darroch, J. Contraceptive Use and Unintended Pregnancy. Glob. libr. women's med.,(ISSN: 1756-2228) 2008; DOI 10.3843/GLOWM.10379. 